\title{
Fibrin Nanostructures for Biomedical Applications
}

\author{
Z. RIEDELOVÁ-REICHELTOVÁ ${ }^{1}$, E. BRYNDA $^{1}$, T. RIEDEL $^{1}$ \\ ${ }^{1}$ Institute of Macromolecular Chemistry of the Czech Academy of Sciences, Prague, Czech \\ Republic
}

Received July 14, 2016

Accepted July 14, 2016

\section{Summary}

Fibrin is a versatile biopolymer that has been extensively used in tissue engineering. In this paper fibrin nanostructures prepared using a technique based on the catalytic effect of fibrin-bound thrombin are presented. This technique enables surface-attached thin fibrin networks to form with precisely regulated morphology without the development of fibrin gel in bulk solution. Moreover, the influence of changing the polymerization time, along with the antithrombin III and heparin concentrations on the morphology of fibrin nanostructures was explored. The binding of bioactive molecules (fibronectin, laminin, collagen, VEGF, bFGF, and heparin) to fibrin nanostructures was confirmed. These nanostructures can be used for the surface modification of artificial biomaterials designed for different biomedical applications (e.g. artificial vessels, stents, heart valves, bone and cartilage constructs, skin grafts, etc.) in order to promote the therapeutic outcome.

\section{Key words}

Fibrinogen - Fibrin-bound thrombin - Nanostructures • Tissue engineering • Biomaterials

\section{Corresponding author}

T. Riedel, Institute of Macromolecular Chemistry of the Czech Academy of Sciences, Heyrovského nám. 2, 16206 Prague 6, Czech Republic. E-mail: riedel@imc.cas.cz

\section{Introduction}

Fibrin is a natural biopolymer formed in the last step of the coagulation cascade after the cleavage of fibrinogen by the catalytic action of thrombin. The coagulation cascade is a series of complex reactions that are initiated upon injury or after blood contact with a foreign material (Schenone et al. 2004). As a result, thrombin is generated in the last step of the coagulation cascade that cleaves fibrinopeptides $\mathrm{A}$ and $\mathrm{B}$ from fibrinogen to form fibrin monomers. These monomers first spontaneously associate into protofibrils in a halfstaggered manner and later form a fibrin network, which is stabilized through cross-linking by factor XIIIa (Ariëns et al. 2002, Weisel and Litvinov 2013). The fibrin, together with platelets and entrapped red blood cells, forms a blood clot that stops bleeding. Moreover, fibrin plays an important role in the wound healing process (Laurens et al. 2006). After the establishment of hemostasis, it functions as a provisional matrix in which cells (e.g. leukocytes, fibroblasts, endothelial cells, smooth muscle cells) can adhere, migrate, proliferate, organize, and perform specialized functions (Shats et al. 1997, Ugarova and Yakubenko 2001, Yee et al. 1998).

Fibrinogen is a glycoprotein composed of three pairs of different peptide chains $(\mathrm{A} \alpha, \mathrm{B} \beta, \gamma)$ packed into an elongated shape with two distal D-regions connected by coiled-coil connectors to a central E-region, where fibrinopeptides A (FpA) and B (FpB) are located (Weisel 2005). The cleavage of these fibrinopeptides by thrombin exposes the polymerization sites " $A$ " and "B", also known as knobs, that are complementary to sites "a" and "b", known as holes, which are permanently present in the fibrinogen molecule. The noncovalent knob-hole interactions (A:a and B:b) play a key role in assembling the fibrin clot (Averett et al. 2008, Litvinov et al. 2005). The release of FpA precedes $\mathrm{FpB}$ in the solution; however, it has been shown that in localized fibrin formation, the FpB cleavage is favored (Blombäck and Bark 2004, Riedel et al. 2011). Fibrin(ogen) is a very complex protein that also interacts with other proteins such as thrombin, tissue plasmin activator, plasminogen, $\alpha_{2}$-antiplasmin, fibronectin, fibroblast growth factor-2, 
vascular endothelial growth factor, and others (Di Cera 2003, Májek et al. 2013, Makogonenko et al. 2002, Podor et al. 2002, Sahni and Francis 2000). The binding of thrombin to fibrin helps to localize the clot at the side of the injury. It has been shown, that unlike thrombin in solution, fibrin-bound thrombin is protected against inhibition by the heparin/antithrombin III complex. However, it can be inhibited by direct thrombin inhibitors such as hirudin (Weitz et al. 1990).

Fibrin is a versatile biopolymer that has been extensively used in various tissue engineering applications (bone, cartilage, skin, vascular, nervous, muscle tissue engineering, etc.) as a biodegradable and biocompatible scaffold (Bacakova et al. 2016, Eyrich et al. 2007, Page et al. 2011, Weber et al. 2014, Willerth et al. 2006, Zhou and Xu 2011). Fibrin is mainly used as an injectable biodegradable scaffold and cell carrier promoting cell growth and differentiation (De La Puente et al. 2011, Li et al. 2015). Fibrin scaffolds were shown to support the growth and capillary formation of endothelial cells (EC), and fibrin gels seeded with EC and vascular smooth muscle cells (VSMC) created a small caliber vascular prosthesis (Koroleva et al. 2012, Yao et al. 2005). Cells interact with fibrin via the specific peptide sequences present on the fibrin surface (RGD), or via the extracellular matrix proteins and growth factors attached to the fibrin (Makogonenko et al. 2002, Podor et al. 2002, Sahni and Francis 2000, Yakovlev et al. 2011). Fibrin contains several RGD sequences that interact with cells and platelets (Laurens et al. 2006). Recently, a novel natural mutation in the RGDF sequence in the coiled coil of fibrinogen was reported (Riedelová-Reicheltová et al. 2013). The natural mutation of phenylalanine to isoleucine made the RGD sequence more visible and dramatically increased platelet adhesion and aggregation. The importance of the RGD sequence was shown on fibrin coated vascular prosthesis crosslinked with RGD peptide that increased EC attachment (Meinhart et al. 2005). In addition, fibrin assemblies coated with collagen, fibronectin, or laminin enabled the formation of more mature focal adhesions containing vinculin and talin on the EC membrane, a precondition of mature endothelium (Filová et al. 2014).

Fibrin can be shaped into desired threedimensional structures, such as blood vessels and heart valves (Jockenhoevel et al. 2001). However, several disadvantages limit the real potential of fibrin scaffolds. The mechanical properties of fibrin are poor and they often lead to fibrin shrinkage because of the contractile forces in the scaffold (Jockenhoevel et al. 2001). Another disadvantage is the fast degradation of fibrin in the body, as well as in the tissue culture, due to plasmin and the proteolytic activity of the cells. Unlike fibrin, synthetic materials offer better mechanical properties, stability, and tunable biodegradability. However, they require surface modifications in order to mediate proper cell-surface interactions which lead to cell attachment, proliferation, and maturation (Mi et al. 2014, Place et al. 2009). Therefore, coating synthetic scaffolds and even porous 3D scaffolds with thin fibrin layers with well controlled architecture might be a promising approach for cell colonization of the construct (Filová et al. 2009, 2014). In addition, the possibility to functionalize the fibrin nanostructures with various biologically active biomolecules (ECM proteins, antibodies, heparin, growth factors, fibrinolysis inhibitors), makes the fibrin surface coating a great tool to decrease the thrombogenicity of various biomaterials, guide cells attachment, and increase proliferation and differentiation of cells. An important issue of fibrin scaffold is the fast degradation by plasmin, an attachment of various plasmin inhibitors or the use of fibrinogen with impaired tissue plasmin activator binding site (t-PA) could lead to improved performance of the fibrin coatings (Kotlín et al. 2010). Furthermore, the technique can be carried out using autologous fibrinogen isolated from the peripheral blood thus eliminating the risk of viral transmission during the preparation of the fibrin coating (De La Puente and Ludeña 2014).

In order to prepare fibrin nanostructures on the surface, a thorough investigation of the architecture is required. The aim of this study was to extend our previous observation on surface fibrin formation and to explore the influence of changing the polymerization time, and the antithrombin III and heparin concentrations on the morphology of fibrin nanostructures. In addition, the binding of various biologically active biomolecules, known to promote cell attachment and proliferation, on the fibrin nanostructures was confirmed by surface plasmon resonance (SPR).

\section{Methods}

\section{Materials}

The fibrinogen, thrombin, heparin, laminin, VEGF 165, and bFGF were purchased from SigmaAldrich. The collagen and fibronectin were purchased from Calbiochem and Merck respectively. The antithrombin III (ATIII) was purchased from 
Chromogenix. All solutions were prepared in the Tris buffer $0.05 \mathrm{M}$, pH 7.4 with $0.1 \mathrm{mM} \mathrm{NaCl}$ and $2.5 \mathrm{mM}$ $\mathrm{CaCl}_{2}$ (TB) filtered through a Millipore $0.22 \mu \mathrm{m}$ filter.

\section{Substrate preparation}

The fibrin nanostructures were prepared on a microscope cover glass. The substrates were soaked for $10 \mathrm{~min}$ in a mixture of sulphuric acid and hydrogen peroxide (2:1), followed by several washing steps in deionized water, and dried in a flow box. The surface roughness of the glass was $<0.25 \mathrm{~nm}$ over $1 \mu \mathrm{m}^{2}$ scanning area.

\section{Sample preparation}

The microscope cover glass was fixed in a flow cell (volume $80 \mu \mathrm{l}$ ), in which solutions were subsequently exchanged with a syringe at room temperature (about $25^{\circ} \mathrm{C}$ ) according to a previously published technique (Riedel et al. 2009). Fibrinogen, at a concentration of $5 \mu \mathrm{g} \cdot \mathrm{ml}^{-1}$ in TB, was allowed to adsorb on substrate surfaces for $120 \mathrm{~min}$. Then, the surface was rinsed several times with $\mathrm{TB}$ and treated with thrombin $2.5 \mathrm{NIH} \mathrm{U} \cdot \mathrm{ml}^{-1}$ for $15 \mathrm{~min}$ and rinsed with $\mathrm{TB}$ again. Finally, a new solution of fibrinogen at a concentration of $200 \mu \mathrm{g} \cdot \mathrm{ml}^{-1}$ containing ATIII or ATIII and heparin (at different concentrations) was introduced. Fibrin formation was stopped by replacing the fibrinogen solution with TB. The fibrin nanostructures were freezedried and measured with AFM. The thickness of the fibrin nanostructures was evaluated using a spectroscopic ellipsometer in a wet and dry state. Thrombin activity was confirmed by the chromogenic substrate S-2238.

\section{Surface plasmon resonance}

SPR based on Kretschmann geometry with wavelength interrogation (UFE ASCR) was used. The sensing chips were fabricated on microscope glass slides by deposition in the vacuum of a thin adhesion chromium layer (thickness $2 \mathrm{~nm}$ ) followed by a gold layer (thickness $50 \mathrm{~nm}$ ). The angle of incidence of the polychromatic beam was adjusted in order to tune the SPR wavelength close to $\lambda_{\mathrm{SPR}}=750 \mathrm{~nm}$. The binding-induced variations in $\lambda_{\text {SPR }}$ were tracked in time by using dedicated software. a flow-cell with four chambers (each with a volume of $1 \mu \mathrm{l})$ was clamped against the SPR chip surface and the fibrinogen, thrombin, and fibrinogen+ATIII+heparin solutions were permitted to flow by using a peristaltic pump with a flow rate of $25 \mu \mathrm{l} \cdot \mathrm{min}^{-1}$. The attachment of bioactive molecules to fibrin nanostructures was observed directly in the SPR for $15 \mathrm{~min}$. The concentrations of individual bioactive molecules were as follows: fibronectin $100 \mu \mathrm{g} \cdot \mathrm{ml}^{-1}$, laminin $100 \mu \mathrm{g} \cdot \mathrm{ml}^{-1}$, collagen type I $100 \mu \mathrm{g} \cdot \mathrm{ml}^{-1}$, VEGF $10 \mu \mathrm{g} \cdot \mathrm{ml}^{-1}$, bFGF $10 \mu \mathrm{g} \cdot \mathrm{ml}^{-1}$, heparin $1 \mathrm{mg} \cdot \mathrm{ml}^{-1}$. All measurements were carried out at $T=25^{\circ} \mathrm{C}$.

\section{Spectroscopic ellipsometer}

The ellipsometric data were acquired using a spectroscopic ellipsometer M2000 (J.A. Woollam Co., USA) operated in rotating compensator mode. All measurements were performed in the wavelength range of 350-1,000 nm with a Xe arc lamp light source and angle of incidence of $60^{\circ}$. For the measurements in water, a liquid cell with a volume of $\mathrm{V}=0.7 \mathrm{ml}$ was used. The obtained data were analyzed with the CompleteEASE software.

\section{Atomic force microscopy (AFM)}

A Multimode Scanning Probe Microscope Nanoscope ${ }^{\circledR}$ IIIa with a longitudinal silicon cantilever OTESPA7 designed for tapping mode in air $(160 \mu \mathrm{m}$, spring constant $42 \mathrm{~N} \cdot \mathrm{m}^{-1}, 1 \Omega \mathrm{cm}$ Silicon tip with tip radius $7 \mathrm{~nm}$ ) was used for the AFM measurements. Freeze dried samples were studied in the tapping mode at a driving frequency of about $350 \mathrm{kHz}$ and an oscillation amplitude $1.4 \mathrm{~V}$. The thickness of the fibrin nanostructures was measured by scratching the surface of the dried samples with tweezers. To avoid damage to the sample, the scan rate was kept as low as possible. The images were evaluated using Gwyddion 2.41 data analysis software (www.gwyddion.net). For each sample, a series of images were collected demonstrating the uniformity of the fibrin nanostructures.

\section{Results and Discussion}

The formation of fibrin nanostructures based on the catalytic effect of fibrin-bound thrombin and the influence of changing the polymerization time, and the ATIII and heparin concentrations are presented. The technique consists of three different steps: fibrinogen adsorption, thrombin treatment, and the polymerization of a new fibrinogen solution that may or may not contain thrombin inhibitors such as ATIII and heparin (Fig. 1). The fibrin-bound thrombin upon contact with the fibrinogen solution initiates the formation of a fibrin network. The polymerization proceeds in the bulk and a thick 3D fibrin network is formed when no thrombin 
inhibitors are present. However, when ATIII or ATIII + heparin are present, then they serve to localize the fibrin clot at the surface, thus allowing to regulate the thickness of the fibrin network (Fig. 1A, B, C).

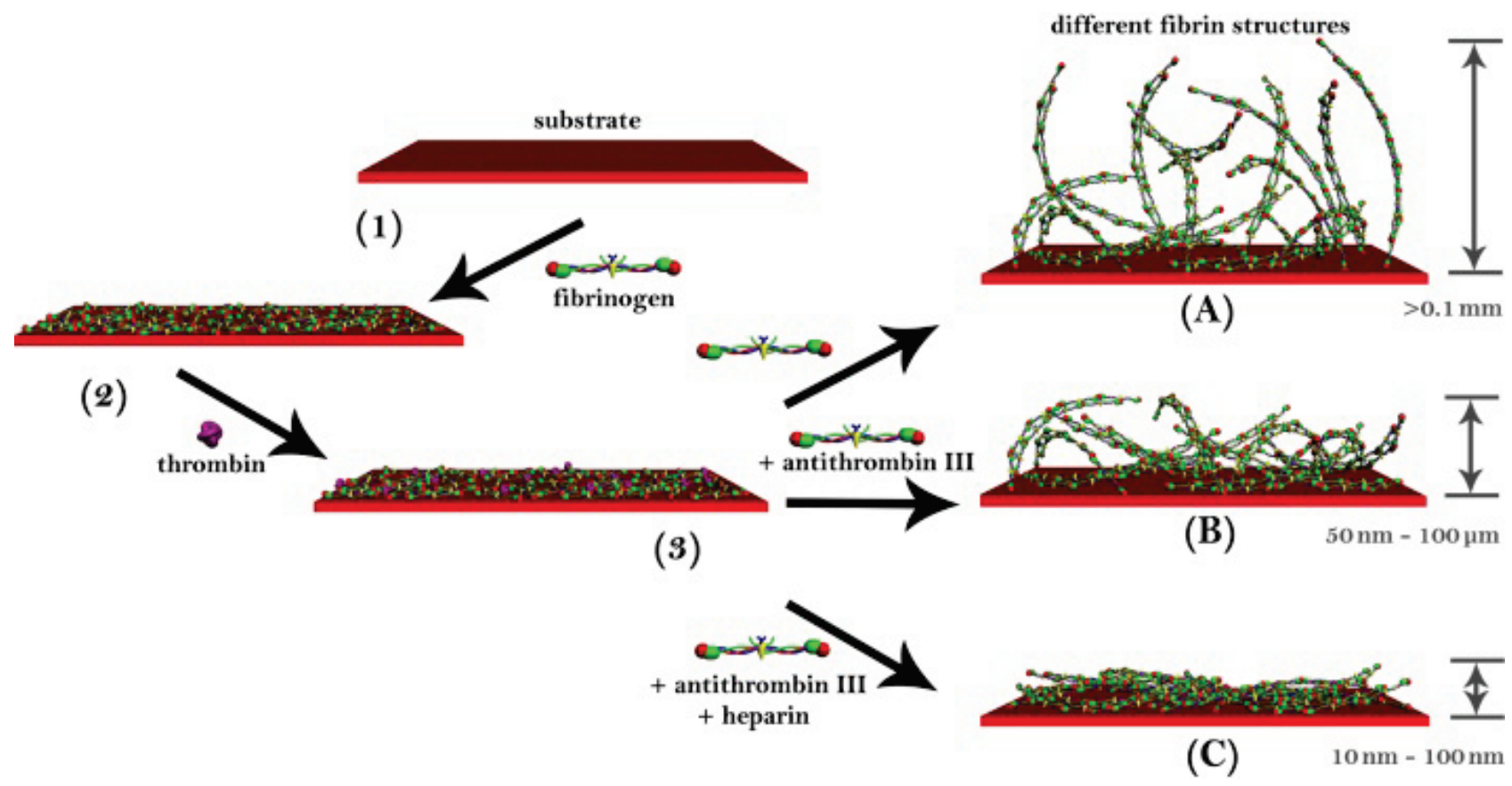

Fig. 1. Scheme of the technique. 1) fibrinogen adsorption on the surface; 2) thrombin treatment; $\mathbf{3}$ ) the initiation of polymerization by adding a new solution of fibrinogen (A - without any inhibitors, B - with ATIII, C - with ATIII and heparin).

\section{Fibrinogen adsorption and interaction with thrombin}

Fibrinogen $\left(5 \mu \mathrm{g} \cdot \mathrm{ml}^{-1}\right.$ in $\left.\mathrm{TB}\right)$ was adsorbed on the surface of a microscope cover glass and treated with thrombin. The adsorption of fibrinogen was observed in situ by SPR. The SPR signal reached a saturation plateau after approximately $120 \mathrm{~min}$. There was no decrease in the signal after exchanging the fibrinogen solution with TB. Based on previous studies, when fibrinogen adsorption was performed from a low-concentration (below $20 \mu \mathrm{g} \cdot \mathrm{ml}^{-1}$ ), a saturated monolayer of fibrinogen molecules oriented in a side-on manner would form on the surface (Fig. 1, step 1).

After the formation of the fibrinogen monolayer, the surface was treated with thrombin for $15 \mathrm{~min}$. Thrombin catalyzes the enzymatic cleavage of fibrinopeptides and it also has the ability to bind to fibrin at two classes of non-substrate sites with low and high affinity. The high affinity binding site is located in the fibrinogen $\gamma$ ' chain variant and it was previously shown, that the fibrin-bound thrombin remained catalytically active (Meh et al. 1996). Direct observation of the thrombin-fibrinogen interaction on the surface was beyond the sensitivity of the SPR measurement. Therefore, the presence of enzymatically active fibrinbound thrombin was confirmed spectroscopically by using the chromogenic substrate for thrombin S-2238. Thrombin splits off p-nitroaniline (a yellow product) from the chromogenic substrate and causes an increase in absorbance at $405 \mathrm{~nm}$. Previous reports showed that thrombin can be released from the surface into the solution, where it polymerizes the formation of the fibrin network in the bulk (Riedel et al. 2009). To avoid the formation of a three-dimensional fibrin network in the bulk and to localize the formation of fibrin on the surface, mechanisms similar to fibrin formation in vivo must be explored, e.g. the use of ATIII.

\section{Fibrin nanostructure formation}

The formation of fibrin nanostructures on the surface started at the moment when a new solution containing fibrinogen and thrombin inhibitor was added to the fibrinogen monolayer treated with thrombin. Welldeveloped fibrin nanostructures on a glass surface were prepared by incubation of the thrombin treated fibrinogen monolayer with fibrinogen $\left(200 \mu \mathrm{g} \cdot \mathrm{ml}^{-1}\right.$ in TB) and ATIII $\left(0.5 \mathrm{U} \cdot \mathrm{ml}^{-1}\right.$ in $\left.\mathrm{TB}\right)$ for $60 \mathrm{~min}$. The AFM visualization of the fibrin nanostructures showed that they consisted of smaller fibers homogenously covering the whole surface and of large fibers sparsely distributed over the surface (Fig. 2). As can be noticed, the large fibers grew from 
smaller fibers on the surface (Fig. 2a, b, c). In addition, we were able to observe very fine structures of the fibrin fibers comparable to transmission electron microscopy data (Weisel et al. 1981). The typical periodic pattern of the fibrin fibers was resolved using an AFM microscope (Fig. 2d). An analysis of the periodicity of several areas revealed that the period was $22.3 \pm 1.9 \mathrm{~nm}$. Such an observation is in good agreement with the TEM micrographs (Weisel et al. 1981), with a high-resolution observation done by AFM (Yermolenko et al. 2011), and by small-angle X-ray scattering studies (Muller and Ferry 1989), where a pattern with a spacing of $22.5 \mathrm{~nm}$ was shown.

\section{Antithrombin III and heparin effect}

ATIII is a natural thrombin inhibitor that possesses over $90 \%$ of total thrombin inhibition in the blood, therefore ATIII plays a key role in blood coagulation and in maintaining hemostasis. The influence of different concentrations of ATIII on the morphology of fibrin nanostructures was evaluated using an AFM. The formation of fibrin nanostructures on the surface started at the moment when a solution containing fibrinogen and ATIII (at different concentrations $0.1 \mathrm{U} \cdot \mathrm{ml}^{-1} ; 0.25 \mathrm{U} \mathrm{ml}^{-1}$; $0.5 \mathrm{U} \cdot \mathrm{ml}^{-1}$; and $0.75 \mathrm{U} \cdot \mathrm{ml}^{-1}$ ) was added to the fibrinogen monolayer treated with thrombin as described earlier, and the mixture was allowed to polymerize for $15 \mathrm{~min}$. The formed fibrin nanostructures considerably differed in their morphology in a concentration dependent manner (Fig. 3 upper row). The thickest fibers and fibrin network were formed with the lowest concentration of ATIII $0.1 \mathrm{U} \cdot \mathrm{ml}^{-1}$, while only dense surface fibrin nanostructures were formed at the highest ATIII concentration $0.75 \mathrm{U} \cdot \mathrm{ml}^{-1}$.
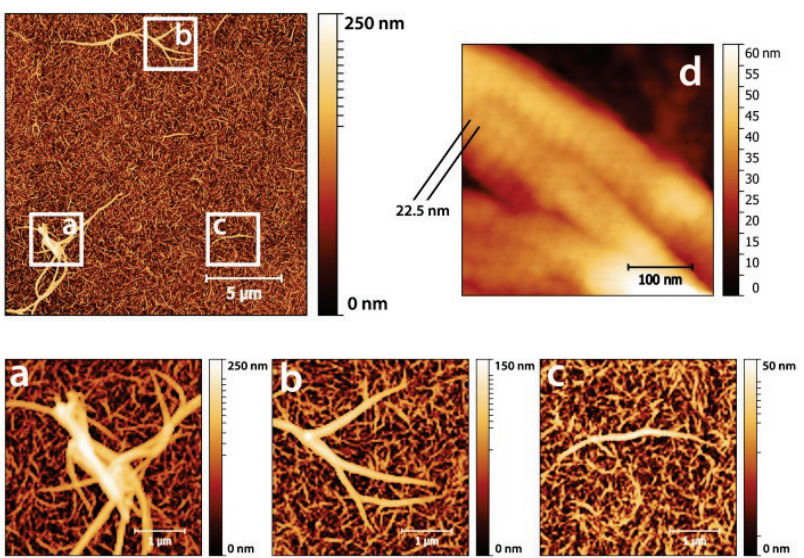

Fig. 2. Fibrin nanostructures grown from the surface using a technique based on the catalytic effect of surface fibrin-bound thrombin and observed in a dry state by AFM. a, b, c) Details of fibrin fibers growing from the surface. d) Detail of a fibrin fiber with a typical periodic pattern of $22.5 \mathrm{~nm}$ observed by AFM. The bar in panels $a, b, c$ is $1 \mu \mathrm{m}$.

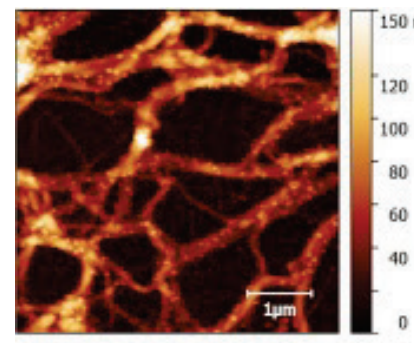

$0.1 \mathrm{U} \cdot \mathrm{ml}^{-1}$

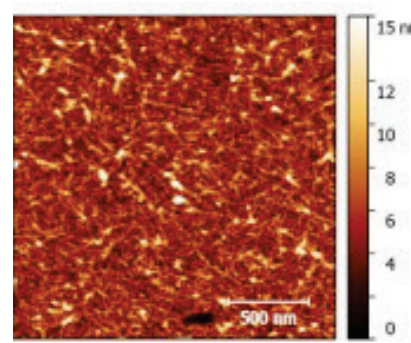

$0.1 \mu \mathrm{g} \cdot \mathrm{ml}^{-1}$

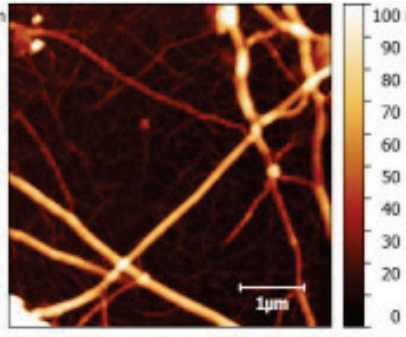

$0.25 \mathrm{U} \cdot \mathrm{ml}^{-1}$

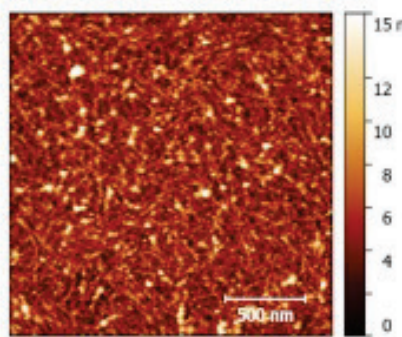

$10 \mu \mathrm{g} \cdot \mathrm{ml}^{-1}$

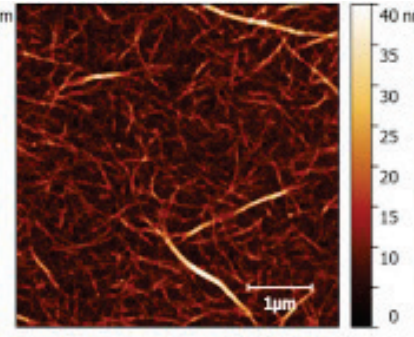

$0.5 \mathrm{U} \cdot \mathrm{ml}^{-1}$

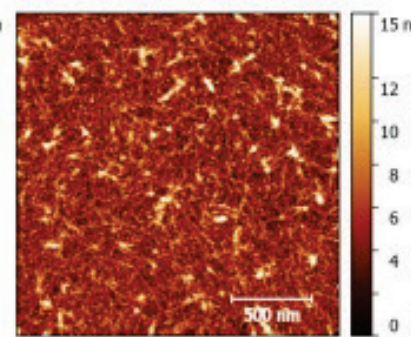

$60 \mu \mathrm{g} \cdot \mathrm{ml}^{-1}$

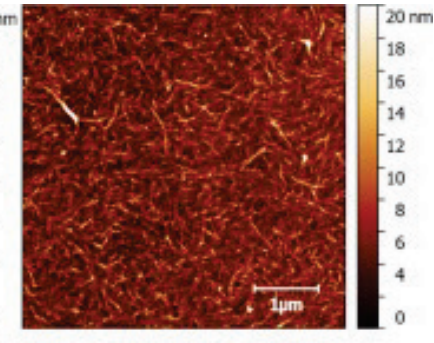

$0.75 \mathrm{U} \cdot \mathrm{ml}^{-1}$

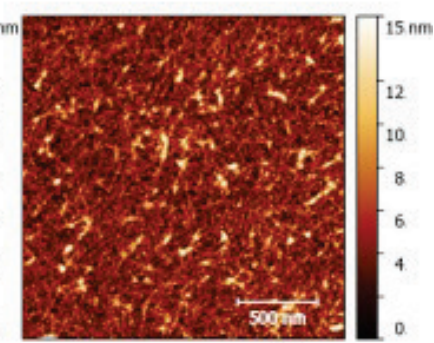

$100 \mu \mathrm{g} \cdot \mathrm{ml}^{-1}$

Fig. 3. The effect of changing the ATIII concentration (upper row) and heparin concentration (lower row) on the morphology of fibrin nanostructures grown from the surface by catalytic effect of fibrin-bound thrombin on fibrinogen solution containing ATIII (upper row) or ATIII and heparin (lower row). The bars are $1 \mu \mathrm{m}$ (upper row) and $500 \mathrm{~nm}$ (lower row). 
Heparin is a polysaccharide that has numerous important biological activities via its interactions with diverse proteins (Capila and Linhardt 2002). It binds to ATIII, causing it conformational changes that greatly accelerate the thrombin inhibition rate (Rosenberg and Damus 1973). The formation of fibrin nanostructures on the surface with different heparin concentrations (0.1-100 $\left.\mu \mathrm{g} \cdot \mathrm{ml}^{-1}\right)$ was evaluated after the polymerization of the fibrinogen solution containing ATIII $\left(0.5 \mathrm{U} \cdot \mathrm{ml}^{-1}\right)$ and heparin on a surface with fibrin-bound thrombin for $15 \mathrm{~min}$. The lower row of Figure 3 shows that heparin does not have a significant effect on fibrin formation. It seems that even at the lowest concentration, heparin was still present in a molar excess to ATIII. Therefore, increasing the concentration did not affect the resulting fibrin structure.

\section{Polymerization time}

The fibrin network formation was monitored in time (after 15, 30, 60, and $120 \mathrm{~min}$ ) using AFM. The obtained data demonstrate that the fibrin morphology was influenced by the time of polymerization. While at shorter times only loosely packed fibrin nanostructures with short fibril length were formed on the surface, with increasing time, the surface becomes coated with thicker and longer fibers. Moreover, the density of the fibrin fibers was increased and the fibrin network homogenously covered the whole surface. The effect of polymerization time was less noticeable in the presence of ATIII $\left(0.5 \mathrm{U} \cdot \mathrm{ml}^{-1}\right)$ and heparin $\left(60 \mu \mathrm{g} \cdot \mathrm{ml}^{-1}\right)$ in the polymerization mixture, whereas in the presence of just ATIII $\left(0.5 \mathrm{U} \cdot \mathrm{ml}^{-1}\right)$ the effect was more apparent (Fig. 4). In order to evaluate the thickness of the fibrin nanostructures in their native state, an SE measurement was carried out. In addition, the thickness of dry samples was measured using AFM and SE. Table 1 summarizes the thickness of the fibrin nanostructures obtained by AFM and SE. It was noticeable that the thickness increased with the polymerization time (from $45 \mathrm{~nm}$ to $68.6 \mathrm{~nm}$ and from $54.3 \mathrm{~nm}$ to $84.2 \mathrm{~nm}$ ) and that higher values were obtained when heparin was absent. This observation was in agreement with the morphology of the fibrin nanostructures obtained by AFM. Moreover, the values obtained from SE correlated well with the AFM data.

By using a technique based on the catalytic activity of fibrin-bound thrombin, homogeneous fibrin nanostructures can be prepared on the substrate surface. In this paper, we chose glass slides as a substrate; however, the fibrin nanostructures can be prepared on virtually any surface (Riedel et al. 2009). The morphology of the fibrin nanostructure can be tuned by changing the ATIII concentration (less ATIII leads to thicker fibrin networks) and/or the polymerization time (longer time leads to denser and thicker fibrin networks). The effect of heparin was negligible.

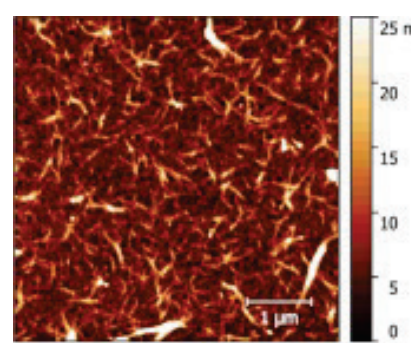

$15 \mathrm{~min}$

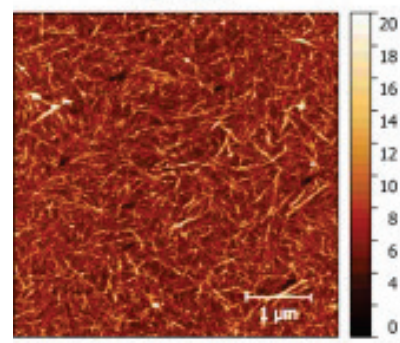

$15 \mathrm{~min}$

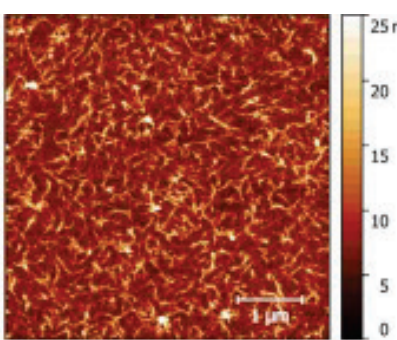

$30 \mathrm{~min}$

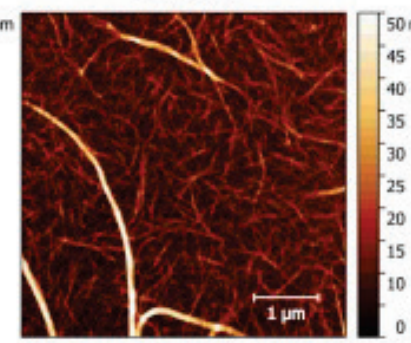

$30 \mathrm{~min}$

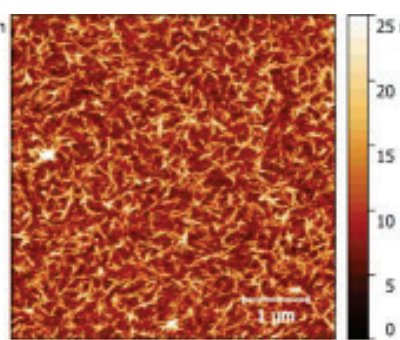

$60 \mathrm{~min}$

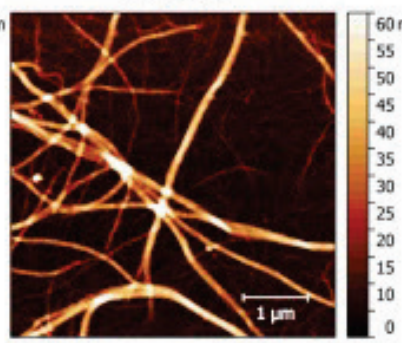

$60 \mathrm{~min}$

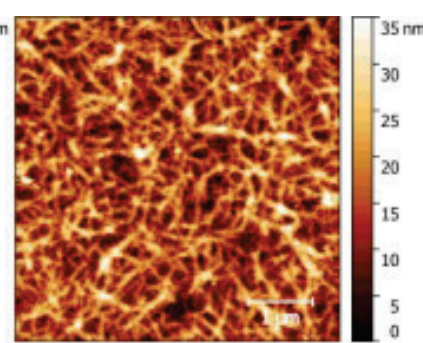

$120 \mathrm{~min}$

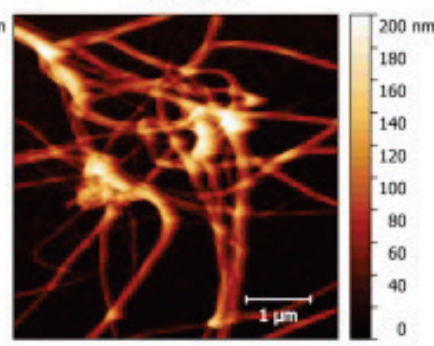

$120 \mathrm{~min}$

Fig. 4. The effect of changing the polymerization time on the morphology of fibrin nanostructures grown from the surface by catalytic effect of fibrin-bound thrombin on fibrinogen solution containing ATIII and heparin (upper row) or ATIII (lower row). The bar is $1 \mu \mathrm{m}$. 
Table 1. The thickness of the fibrin nanostructures measured by a spectroscopic ellipsometer (SE) and atomic force microscopy (AFM). The fibrin nanostructures were prepared by catalytic action of fibrin-bound thrombin on fibrinogen solution containing ATIII or ATIII and heparin. The polymerization time was 30 and $120 \mathrm{~min}$.

\begin{tabular}{lcccc}
\hline & $\begin{array}{c}\text { Polymerization } \\
\text { time [min] }\end{array}$ & $\begin{array}{c}\text { Thickness (SE) } \\
{[\mathbf{n m}]}\end{array}$ & $\begin{array}{c}\text { Thickness in dry } \\
\text { state (SE) [nm] }\end{array}$ & $\begin{array}{c}\text { Thickness in dry } \\
\text { state (AFM) [nm] }\end{array}$ \\
\hline $\begin{array}{l}\text { Fibrinogen }+ \\
\text { Antithrombin III }+\end{array}$ & 30 & 45.0 & 11.3 & 10.2 \\
$\begin{array}{l}\text { Heparin } \\
\text { Fibrinogen }+\end{array}$ & 120 & 68.6 & 20.4 & 19.0 \\
Antithrombin III & 30 & 54.3 & 28.5 & 20.6 \\
\hline
\end{tabular}

Fibrin nanostructures for biomedical applications

The attachment of various bioactive biomolecules on the fibrin nanostructures was observed by SPR. The fibrin nanostructures on the SPR chip were formed by polymerization of a fibrinogen solution containing ATIII $\left(0.5 \mathrm{U} \cdot \mathrm{ml}^{-1}\right)$ and heparin $\left(60 \mu \mathrm{g} \cdot \mathrm{ml}^{-1}\right)$. This type of fibrin nanostructure was chosen in order to avoid blockage of the SPR tubings. Figure 5 shows the attachment of fibronectin, laminin, collagen I, VEGF, bFGF, and heparin to the fibrin nanostructure observed by SPR in situ for $15 \mathrm{~min}$. The surface density of the attached proteins and glycosaminoglycans can be estimated as: fibronectin- $20 \mathrm{ng} \cdot \mathrm{cm}^{-2}$, laminin- $6.8 \mathrm{ng} \cdot \mathrm{cm}^{-2}$, collagen I-17.7 $\mathrm{ng} \cdot \mathrm{cm}^{-2}$, VEGF-121 $\mathrm{ng} \cdot \mathrm{cm}^{-2}$, bFGF-
$103.5 \mathrm{ng} \cdot \mathrm{cm}^{-2}$, heparin-20.6 $\mathrm{ng} \cdot \mathrm{cm}^{-2}$. It should be noted that the amount of attached proteins on the fibrin nanostructures can be easily tuned by changing the adsorption time. This is extremely important especially when growth factors are used in tissue culture and in implants, as they may cause adverse reactions such as tumor growth, decreased cell proliferation, differentiation, and survival (Turner and Grose 2010, Verheul and Pinedo 2000). In this paper, we selected some representative bioactive molecules to highlight the ease of functionalization. A plethora of other biomolecules for specific functions can be immobilized in analogous fashion.
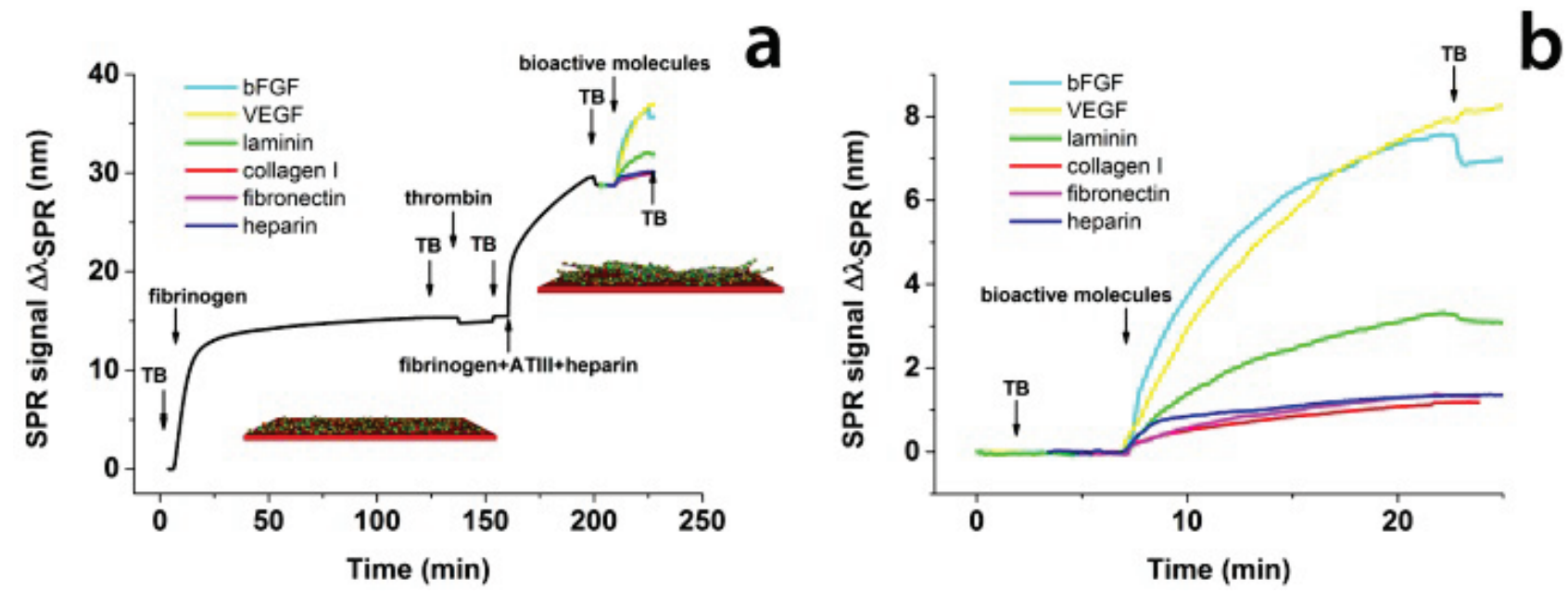

Fig. 5. SPR sensorgram showing: a) the preparation of fibrin nanostructures by the catalytic action of fibrin-bound thrombin on fibrinogen solution containing ATIII and heparin, and the attachment of bioactive molecules; $\mathbf{b}$ ) detail on the attachment of biologically active molecules to the fibrin nanostructure prepared by fibrin-bound thrombin. The arrows indicate the replacement of solutions. TB Tris buffer pH 7.4, bFGF - basic fibroblast growth factor, VEGF - vascular endothelial growth factor.

The fibrin nanostructures prepared herein offer several advantages for tissue engineering and scaffold modification: the fibrin nanostructures can be prepared on virtually any surface; they are biodegradable and biocompatible; the morphology and thickness can be tuned by changing the polymerization conditions; they 
can be functionalized with various biologically active biomolecules to promote cell attachment, proliferation, and differentiation; to decrease thrombogenicity of the scaffold; to decrease platelet adhesion and aggregation; etc. Another advantage is that fibrinogen can be easily isolated from blood plasma, thus providing autologous material.

\section{Conclusions}

This paper evaluated the influence of differing ATIII and heparin concentrations and varied polymerization times on the morphology of fibrin nanostructures grown by a technique based on surface fibrin-bound thrombin. Different combinations of thrombin inhibitors led to various thicknesses and the appearance of the fibrin nanostructure. The use of heparin and ATIII during the fibrin polymerization led to densely packed fibrin on the surface, while when only ATIII was used, thick fibrin fibers and networks grew from the surface and reached up to hundreds of nanometers in height. As expected, by increasing the polymerization time, denser and thicker fibrin nanostructures were formed on the surface. By decreasing the concentration of ATIII, fibrin formation was accelerated and a thick network formed within a short time. On the other hand, the effect of different concentrations of heparin was negligible. Importantly, the surface-bound fibrin nanostructures can be functionalized with various biologically active biomolecules - e.g. extracellular matrix proteins (fibronectin, laminin, collagen I), growth factors (VEGF and bFGF), and proteoglycan heparin. The amount of the biologically active molecules attached to the fibrin can be regulated. The technique can be used as a biomimetic coating of wide range of artificial biomaterials and scaffolds in order to selectively promote cell attachment, proliferation, and differentiation, and to improve hemocompatibility. Another important attribute of this technique is that it can be applied to coat the surface of $3 \mathrm{D}$ porous scaffolds without filling the pores with a bulk fibrin network generally observed when traditional techniques of fibrin formation are used, therefore allowing cells to penetrate into the material. In addition, autologous fibrinogen can be easily isolated from blood plasma.

\section{Conflict of Interest}

There is no conflict of interest.

\section{Acknowledgements}

This work was supported by the Ministry of Education, Youth and Sports of CR within the National Sustainability Program II, Project BIOCEV-FAR LQ1604.

\section{References}

ARIËNS RAS, LAI TS, WEISEL JW, GREENBERG CS, GRANT PJ: Role of factor XIII in fibrin clot formation and effects of genetic polymorphisms. Blood 100: 743-754, 2002.

AVERETT LE, GEER CB, FUIERER RR, AKHREMITCHEV BB, GORKUN OV, SCHOENFISCH MH: Complexity of "A-a" knob-hole fibrin interaction revealed by atomic force spectroscopy. Langmuir 24: 4979-4988, 2008.

BACAKOVA M, MUSILKOVA J, RIEDEL T, STRANSKA D, BRYNDA E, ZALOUDKOVA M, BACAKOVA L: The potential applications of fibrin-coated electrospun polylactide nanofibers in skin tissue engineering. Int $J$ Nanomed 11: 771-789, 2016.

BLOMBÄCK B, BARK N: Fibrinopeptides and fibrin gel structure. Biophys Chem 112: 147-151, 2004.

CAPILA I, LINHARDT RJ: Heparin - Protein interactions. Angew Chem Int Ed Engl 41: 390-412, 2002.

DE LA PUENTE P, LUDEÑA D: Cell culture in autologous fibrin scaffolds for applications in tissue engineering. Exp Cell Res 322: 1-11, 2014.

DE LA PUENTE P, LUDEÑA D, FERNÁNDEZ A, ARANDA JL, VARELA G, IGLESIAS J: Autologous fibrin scaffolds cultured dermal fibroblasts and enriched with encapsulated bFGF for tissue engineering. $J$ Biomed Mater Res Part A 99: 648-654, 2011.

DI CERA E: Thrombin interactions. Chest 124 (Suppl 3): 11S-17S, 2003.

EYRICH D, BRANDL F, APPEL B, WIESE H, MAIER G, WENZEL M, STAUDENMAIER R, GOEPFERICH A, BLUNK T: Long-term stable fibrin gels for cartilage engineering. Biomaterials 28: 55-65, 2007. 
FILOVÁ E, BRYNDA E, RIEDEL T, BAČÁKOVÁ L, CHLUPÁČ J, LISÁ V, HOUSKA M, DYR JE: Vascular endothelial cells on two- and three-dimensional fibrin assemblies for biomaterial coatings. $J$ Biomed Mater Res A 90: 55-69, 2009.

FILOVÁ E, BRYNDA E, RIEDEL T, CHLUPÁČ J, VANDROVCOVÁ M, ŠVINDRYCH Z, LISÁ V, HOUSKA M, PIRK J, BAČÁKOVÁ L: Improved adhesion and differentiation of endothelial cells on surface-attached fibrin structures containing extracellular matrix proteins. J Biomed Mater Res A 102: 698-712, 2014.

JOCKENHOEVEL S, ZUND G, HOERSTRUP SP, CHALABI K, SACHWEH JS, DEMIRCAN L, MESSMER BJ, TURINA M: Fibrin gel - advantages of a new scaffold in cardiovascular tissue engineering. Eur $J$ CardioThorac Surg 19: 424-430, 2001.

KOROLEVA A, GITTARD S, SCHLIE S, DEIWICK A, JOCKENHOEVEL S, CHICHKOV B: Fabrication of fibrin scaffolds with controlled microscale architecture by a two-photon polymerization-micromolding technique. Biofabrication 4: 015001, 2012.

KOTLÍN R, REICHELTOVÁ Z, SUTTNAR J, SALAJ P, HRACHOVINOVÁ I, RIEDEL T, MALÝ M, ORAVEC M, KVASNIČKA J, DYR JE: Two novel fibrinogen variants in the C-terminus of the B $\beta$-chain: Fibrinogen Rokycany and fibrinogen Znojmo. J Thromb Thrombolysis 30: 311-318, 2010.

LAURENS N, KOOLWIJK P, DE MAAT MP: Fibrin structure and wound healing. J Thromb Haemost 4: 932-939, 2006.

LI Y, MENG H, LIU Y, LEE BP: Fibrin gel as an injectable biodegradable scaffold and cell carrier for tissue engineering. ScientificWorldJournal 2015: 685690, 2015.

LITVINOV RI, GORKUN OV, OWEN SF, SHUMAN H, WEISEL JW: Polymerization of fibrin: Specificity, strength, and stability of knob-hole interactions studied at the single-molecule level. Blood 106: 2944-2951, 2005.

MÁJEK P, RIEDELOVÁ-REICHELTOVÁ Z, SUTTNAR J, PEČÁNKOVÁ K, ČERMÁK J, DYR JE: Plasma proteome changes associated with refractory anemia and refractory anemia with ringed sideroblasts in patients with myelodysplastic syndrome. Proteome Sci 11: 2013.

MAKOGONENKO E, TSURUPA G, INGHAM K, MEDVED L: Interaction of fibrin(ogen) with fibronectin: Further characterization and localization of the fibronectin-binding site. Biochemistry 41: 7907-7913, 2002.

MEH DA, SIEBENLIST KR, MOSESSON MW: Identification and characterization of the thrombin binding sites on fibrin. J Biol Chem 271: 23121-23125, 1996.

MEINHART JG, SCHENSE JC, SCHIMA H, GORLITZER M, HUBBELL JA, DEUTSCH M, ZILLA P: Enhanced endothelial cell retention on shear-stressed synthetic vascular grafts precoated with RGD-cross-linked fibrin. Tissue Eng 11: 887-895, 2005.

MI HY, JING X, TURNG LS: Fabrication of porous synthetic polymer scaffolds for tissue engineering. $J$ Cell Plast 51: 165-196, 2014.

MULLER MF, FERRY JD: Small-angle X-ray scattering studies of fibrin film: Comparisons of fine and coarse films prepared with thrombin and ancrod. Biopolymers 28: 1011-1018, 1989.

PAGE RL, MALCUIT C, VILNER L, VOJTIC I, SHAW S, HEDBlOM E, HU J, PINS GD, ROLLE MW, DOMINKO T: Restoration of skeletal muscle defects with adult human cells delivered on fibrin microthreads. Tissue Eng Part A 17: 2629-2640, 2011.

PLACE ES, GEORGE JH, WILLIAMS CK, STEVENS MM: Synthetic polymer scaffolds for tissue engineering. Chem Soc Rev 38: 1139-1151, 2009.

PODOR TJ, CAMPBELL S, CHINDEMI P, FOULON DM, FARRELL DH, WALTON PD, WEITZ JI, PETERSON $\mathrm{CB}$ : Incorporation of vitronectin into fibrin clots. Evidence for a binding interaction between vitronectin and $\gamma \mathrm{A} / \gamma^{\prime}$ fibrinogen. J Biol Chem 277: 7520-7528, 2002.

RIEDEL T, BRYNDA E, DYR JE, HOUSKA M: Controlled preparation of thin fibrin films immobilized at solid surfaces. J Biomed Mater Res Part A 88: 437-447, 2009.

RIEDEL T, SUTTNAR J, BRYNDA E, HOUSKA M, MEDVED L, DYR JE: Fibrinopeptides a and B release in the process of surface fibrin formation. Blood 117: 1700-1705, 2011.

RIEDELOVÁ-REICHELTOVÁ Z, KOTLÍN R, SUTTNAR J, GEIEROVÁ V, RIEDEL T, MÁJEK P, DYR JE: A novel natural mutation $\mathrm{A} \alpha \mathrm{Phe} 98 \mathrm{Il}$ in the fibrinogen coiled-coil affects fibrinogen function. Thromb Haemost 111: 79-87, 2013. 
ROSENBERG RD, DAMUS PS: The purification and mechanism of action of human antithrombin heparin cofactor. J Biol Chem 248: 6490-6505, 1973.

SAHNI A, FRANCIS CW: Vascular endothelial growth factor binds to fibrinogen and fibrin and stimulates endothelial cell proliferation. Blood 96: 3772-3778, 2000.

SCHENONE M, FURIE BC, FURIE B: The blood coagulation cascade. Curr Opin Hematol 11: 272-277, 2004.

SHATS EA, NAIR CH, DHALL DP: Interaction of endothelial cells and fibroblasts with modified fibrin networks: Role in atherosclerosis. Atherosclerosis 129: 9-15, 1997.

TURNER N, GROSE R: Fibroblast growth factor signalling: from development to cancer. Nat Rev Cancer 10: 116-129, 2010.

UGAROVA TP, YAKUBENKO VP: Recognition of fibrinogen by leukocyte integrins. Ann N Y Acad Sci 936: 368$385,2001$.

VERHEUL HM, PINEDO HM: The role of vascular endothelial growth factor (VEGF) in tumor angiogenesis and early clinical development of VEGF-receptor kinase inhibitors. Clin Breast Cancer 1 (Suppl 1): S80-S84, 2000.

WEBER M, HETA E, MOREIRA R, GESCHE VN, SCHERMER T, FRESE J, JOCKENHOEVEL S, MELA P: Tissue-engineered fibrin-based heart valve with a tubular leaflet design. Tissue Eng Part C 20: 265-275, 2014.

WEISEL JW: Fibrinogen and fibrin. Adv Protein Chem 70: 247-299, 2005.

WEISEL JW, LITVINOV RI: Mechanisms of fibrin polymerization and clinical implications. Blood 121: 1712-1719, 2013.

WEISEL JW, PHILLIPS GN JR, COHEN C: A model from electron microscopy for the molecular structure of fibrinogen and fibrin. Nature 289: 263-267, 1981.

WEITZ JI, HUDOBA M, MASSEL D, MARAGANORE J, HIRSH J: Clot-bound thrombin is protected from inhibition by heparin-antithrombin III but is susceptible to inactivation by antithrombin III-independent inhibitors. $J$ Clin Invest 86: 385-391, 1990.

WILLERTH SM, ARENDAS KJ, GOTTLIEB DI, SAKIYAMA-ELBERT SE: Optimization of fibrin scaffolds for differentiation of murine embryonic stem cells into neural lineage cells. Biomaterials 27: 5990-6003, 2006.

YAKOVLEV S, GAO Y, CAO C, CHEN L, STRICKLAND DK, ZHANG L, MEDVED L: Interaction of fibrin with VE-cadherin and anti-inflammatory effect of fibrin-derived fragments. J Thromb Haemost 9: 1847-1855, 2011.

YAO L, SWARTZ DD, GUGINO SF, RUSSELL JA, ANDREADIS ST: Fibrin-based tissue-engineered blood vessels: Differential effects of biomaterial and culture parameters on mechanical strength and vascular reactivity. Tissue Eng 11: 991-1003, 2005.

YEE KO, ROONEY MM, GIACHELLI CM, LORD ST, SCHWARTZ SM: Role of $\beta 1$ and $\beta 3$ integrins in human: Smooth muscle cell adhesion to and contraction of fibrin clots in vitro. Circ Res 83: 241-251, 1998.

YERMOLENKO IS, LISHKO VK, UGAROVA TP, MAGONOV SN: High-resolution visualization of fibrinogen molecules and fibrin fibers with atomic force microscopy. Biomacromolecules 12: 370-379, 2011.

ZHOU H, XU HHK: The fast release of stem cells from alginate-fibrin microbeads in injectable scaffolds for bone tissue engineering. Biomaterials 32: 7503-7513, 2011. 